\title{
Relationship building in Vietnamese English written business communication: A systemic functional analysis
}

\author{
Bich H N Nguyen ${ }^{*}$ and Rhonda Oliver
}

\author{
* Correspondence: \\ ngocbich.nguyenhuynh@postgrad. \\ curtin.edu.au \\ Curtin University, Kent Street, \\ Bentley, WA 6102, Australia
}

\begin{abstract}
English has a long history in Vietnam and in the last two decades, particularly for business communication, it has developed with an unprecedented speed. Despite this ascendancy, there is an absence of research regarding English in Vietnamese business correspondence. The current study is an in-depth investigation of this with a particular focus on the written features of English, reflecting the importance of written documents in this context. This research was framed within the theoretical perspectives of Systemic Functional Linguistics (SFL). 303 business texts from various business sectors composed by Vietnamese writers were collected. They were then analysed with regard to four SFL variables: speech functions, mood, modality and terms of address to establish the nature of the interpersonal written features developing within Vietnam. The findings of the study indicate that the writers employed several linguistic strategies (e.g., using Vietnamese kinship terms and Vietnamese lexis) and non-linguistic strategies (e.g., using emoticons and written giggling) to establish a close relationship with their interactants. Relationship building was also reflected in the employment of politeness strategies to achieve positive politeness effect. These results suggest that SFL is a useful theoretical framework and analytical tool to uncover how English is employed in different socio-cultural contexts to enact social meaning-making processes.
\end{abstract}

Keywords: Vietnamese English; Systemic functional linguistics; Relationship building; Business communication; Emails

\section{Introduction}

The diverse forms and functions of Englishes in different continents have triggered substantial research investigating "the varied and continually evolving social and cultural characteristics of the language" (B. Kachru, Y. Kachru, and Nelson 2008: xvii). In South East Asia where Vietnam is geographically located, there have been numerous studies regarding localised varieties of English, such as Thai English (Watkhaolarm 2005), Singapore English (Tan-Chia, Fang, and Ang 2013; Kim and Sato 2013; Smakman and Wagenaar 2013), and Malaysian English (Gut, Pillai, and Don 2013). In Vietnam, despite the significant status, features and functions of English used in written business communication, there is a dearth of empirical studies about these issues (Bautista and Gonzalez 2008). Within that context, the current study examines 
whether systematic interpersonal features of English have emerged in written Vietnamese business communication.

\section{Background}

\section{English in Vietnam}

English was introduced to South Vietnam in 1957 because of the political involvement of the United States in the region at that time (Tran 1998; Do, H Thinh 2006). From that period onwards the number of people learning English in the south of the country increased dramatically as it was perceived to be a means for advancement in society (Wright 2002). This vigorous growth of English, however, lasted for less than three decades and English use in South Vietnam went into a steep decline when Vietnam was reunified in 1975 and joined the communist bloc (Le, Son 2011). English was then marginalised and instead Russian was the primary foreign language to be learnt (Do, H Thinh 2006).

With the economic reformations that occurred in 1986 English once again became popular. Denham (1992) observed that English was readily used between Vietnamese people and non-Vietnamese in metropolitan areas. Even in Hanoi, the capital of Vietnam, where from 1954 Russian was the sole foreign language used due to the North's political alliance with that country (Le, Son 2011), by the beginning of the twenty-first century English was claimed to be taking hold (Lamb 2000). Vietnamese people have been observed making use of any chance to practice their English with English speakers, in hotel lobbies, at tourist destinations, and in the streets (Denham 1992; Mydans 1995). Over time, knowing English has become important to secure office employment as most employers require white-collar applicants to have at least a functional command of the language (Wright 2002; Do 2006). Not only does English play a critical role within private corporations, government employees under the age of 50 are also expected to be conversant in English (Lamb 2000). In fact, in 1997, the then Vietnamese Prime Minister Vo Van Kiet ruled that government officials would not be hired unless they had an advanced command of a foreign language, preferably English (Wilhelm 1995).

This "English-language boom" (Mydans 1995: 4.16) is the context for the current research project. It was motivated by observations made in situ by the first author of the written business communication in Vietnamese corporations, not only between Vietnamese people and non-Vietnamese, but, remarkably, also among Vietnamese speakers themselves. For example:

\section{(1) Dear A. A.}

Dear older brother A

"Dear older brother A,"

There's been no new FA of L'AM, $M$ is very busy \& can't go there tomorrow, my guys will be there to change new Control module of Girbau big washer when finish the installations \& services of NT.

Regards

$X($ text 3-6-X)

In today's business world there is a heavy reliance on written documents for sharing information, conducting and recording transactions, exchanging ideas, and maintaining 
a harmonious interpersonal relationship within a company and with external business contacts (Poe 2006; Xu 2012). As Bruce, Hirst and Keene (1995) put it, "today's world of business lives on written documents" (p. 1). And it seems much of this is occurring in English in Vietnam.

Although the nature of Vietnamese English business communication is "a source of comment and curiosity", there is a dearth of research in this area (van Horn 2008: 622). At the same time, given the importance of written business communication and the rise of English in Vietnam, there is a need to explore this further. Therefore, this study sought to investigate the features of written English for business communication in Vietnam, with a particular focus on the way interpersonal relationships are conveyed in written texts.

\section{Systemic functional linguistics}

The current study is one of those that examine the "realities of the presence of Englishes in their worldwide contexts" (B. Kachru, Y. Kachru, and Nelson 2006: xvii). However, the study did not utilise 'native-speaker' norms as a point of comparison, but allowed the features of English business communication in Vietnam to emerge autonomously from the data. Moreover, instead of focusing on "loan words and fossilised expressions" (Krishnaswamy and Burde 1998: 150) and in order to capture the cultural and situational contexts, this study examined the texts from a functional semiotic perspective. To achieve these ends, Systemic Functional Linguistics (SFL) (Eggins 2004; Halliday 2009; Martin 2009; Matthiessen 2013; Halliday and Matthiessen 2013) was chosen to articulate the theoretical stance that is woven throughout the study. It was also used as the analytical framework for the data analysis.

According to SFL, language is a semiotic system, a meaning-making process (Halliday 1978; Halliday and Matthiessen 2013). Thus, how speakers/writers use language to "construe reality and enact social relationships" (Webster 2009: 1) may actually have more significance than what structural forms they use. Put differently, lexicogrammatical forms are only a means to an end as they are the resources that enable language users to construe events and relate to each other in different ways (Halliday 2009). In business communication, as will be seen in the current study, linguistic forms are the constituents of a semiotic system which the communicators select to create their reality while ensuring the establishment of an interpersonal relationship with respect to power and solidarity. Therefore, SFL, a grammar that "respects speakers' rights to make up their own minds about how they choose to talk" (Martin, Matthiessen, and Painter 1997: 3) has been used to analyse the data because it enables the development of a deep understanding of why the texts were the way they were, rather than judging them on a comparative and linguistic basis.

Because SFL does not explore features in isolation, but in "a totality of relations in all linguistic strata" (Halliday 2009: 65) its use also enables a comprehensive exploration of the texts in full, rather than identification of features that do not conform to certain standards. In other words, it enables language features to be investigated as complete paradigmatic systems (Halliday 2009: 66). Also by looking at the data through the systemic features of speech functions, mood, modality and terms of address, the analysis of the data avoids a deficit approach and instead allows a full description of that variety of English used in Vietnam for business - representing and construing the reality in 
which the particular users live (Mahboob and Szenes 2010). This socio-semantic explanation allows the features of the texts to be viewed in terms of functionality, rather than from a generalised nationality/ethnicity-driven perspective. The employment of SFL as an overarching theoretical framework, therefore, appears most useful for this study to navigate away from a nationally marked variety of English to acknowledge the influence of such dynamic factors as the domain of communication, communication goals and, of key importance to this study, social relationships.

Based on the theoretical framework and the background outlined above, this study examines the variety of English used by Vietnamese business people, aiming to investigate whether endonormative uses (i.e., a local language form) of English have emerged. As such this study addresses the following research questions:

- What are the features of speech functions, mood, modality and terms of address used in Vietnamese English business texts?

- What do they tell us about how interpersonal relationships are being construed through language by Vietnamese writers?

- To what extent does the nature of English used for interpersonal purposes in Vietnamese written business communication support arguments regarding the existence of a 'Vietnamese' variety of English?

\section{Methods}

\section{Data collection}

Ten Vietnamese-owned companies located in three major industrial cities in South Vietnam (i.e., Ho Chi Minh City, Dong Nai and Vung Tau) were approached to participate in this study. The nine companies from which textual data were obtained were fully informed of relevant aspects of the research through an information sheet. Their permission for the analysis of the texts was sought. The companies were also advised of the opportunity to withdraw from the project at any point of time without prejudice or negative consequences. 303 texts composed by Vietnamese writers working within these companies were selected.

It must be noted that several difficulties arose during the data collection process. In spite of the project's ethic approval with regard to the protection of privacy, one company (a bank) refused to take part in the study due to the confidentiality of their business information. Some others were reserved about contributing texts. For instance, it took three months for company 6 to consent to participate in the project as the issue of text donation had to be discussed at a number of internal meetings. This challenge is consistent with what van Horn (2008) observed: A major barrier to research on the uses of English in commerce is restricted access to written data inside organisations.

Moreover, whilst the aim was to collect written business texts of various text types, all the texts donated were emails. Although some application letters were provided, these were only in an electronic form. Such data may, however, reflect a new trend in this era of technology. As Evans (2012) asserts, communication in the workplace has been revolutionised by the dominance of emails. Table 1 illustrates the specific number of e-messages obtained from each company. 
Table 1 Number of texts donated by the participating companies

\begin{tabular}{|c|c|c|c|c|c|c|c|c|c|}
\hline Co. & 1 & 2 & 3 & 4 & 5 & 6 & 7 & 8 & 9 \\
\hline Business sector & Hospitality & $\begin{array}{l}\text { Import-export } \\
\text { (electrical goods) }\end{array}$ & Chemical & $\begin{array}{l}\text { Container } \\
\text { trading }\end{array}$ & $\begin{array}{l}\text { Tertiary education (communication } \\
\text { among staff) }\end{array}$ & Pottery trading & Plastic manufacturing & Health care & $\begin{array}{l}\text { English teaching (communication } \\
\text { among staff) }\end{array}$ \\
\hline $\begin{array}{l}\text { Number of } \\
\text { texts }\end{array}$ & 10 & 29 & 40 & 15 & 30 & 39 & 40 & 68 & 32 \\
\hline
\end{tabular}




\section{Data analysis}

The research method applied in this project, content analysis (CA, Krippendorff 2004; Neuendorf 2002), was selected for two reasons: 1) It revealed the presentational subtleties of the texts, which helped address the first and second research questions. 2) It enabled access to information that might be difficult or even impossible to obtain through direct observation and other means, which helped address the third research question.

To apply CA in this study, a codebook was developed for the analysis of interpersonal meanings of each text at the clause level based on the following SFL lexicogrammatical categories:

\section{Speech functions and mood}

This category was used to examine the power-distance relation between the reader and writer via the (in)congruence between speech functions and mood choice.

To do this, first the speech functions within the texts were identified. Halliday and Matthiessen (2013) contend that, while there is a vast range of speech functions in the English language, they concern either giving or demanding commodity. Depending on the context, this commodity can be either goods and services or information. The exchange of goods and services gives rise to the speech functions of commands and offers (i.e., proposals), whereas the exchange of information involves the speech functions of statements and questions (i.e., propositions). Therefore, in the current analysis texts were coded according to whether they contained commands, offers, statements or questions. It must be noted that in the SFL context, these are not used in the ordinary sense of such terms (Fairclough 2003).

The clauses in each text were then examined to ascertain the type of structures contained within the data. Specifically the data was coded for declaratives (full or elliptical), interrogatives (Wh- or Yes/No) and imperatives.

As a final step, the congruency of mood, or lack thereof, was identified for each structure. For example, the choice of congruent imperative mood as in Please have a look and give me your comment (text 8-6-O) to realise requests indicates a close relationship, frequent contact, and/or possible high affective involvement (Eggins 2004; Painter 2009). In contrast, the incongruent interrogative mood to realise a request as in Would you confirm your mail receipt? (text 9-1-A) indicates unequal power, a distant relationship, infrequent contact and/or low affective involvement (Eggins 2004).

\section{Modality}

This variable was used to analyse the writers' judgement of the probabilities, or the obligations implied within the text (Halliday and Matthiessen 2013). In SFL, there are four kinds of modality: probability, usuality, obligation and readiness. As an illustration, the choice of the obligation modality should as in It should be submitted to PD Acountant $\operatorname{asap}^{1}$ (text 3-3-A) indicates a different level of obligation from will as in You will start off on an hourly rate contract (text 9-29-U) or the lack of modality as in Please send the offer from your end (text 3-9-D).

Therefore, in the current study the texts were examined to determine the proportion of clauses represented by probability, usuality, obligation and readiness. The data in each of these categories were then examined to determine the 
realisation of the modality as either 1) congruent (and within this implicitly subjective or objective) or 2) metaphorical (and within this either explicitly subjective or objective).

\section{Address terms or vocatives}

A vocative embodies "an interpersonal attitude, an endearment" (Martin et al. 1997: 59). It is claimed that the choice of vocatives reveals important interpersonal meanings (Fawcett 2008). For instance, when power is equal, vocative choice is reciprocal, that is, both interactants will use each other's first names. When power is unequal, the choice of vocatives is non-reciprocal so one interactant addresses the other by his/her first name while the other addresses him/her by a title (Eggins 2004). In addition, the use of nicknames, diminutives, terms of endearment or the lack of vocatives also signifies the interpersonal relationship between the writer and reader (Fawcett 2008). Therefore, in this category the use of such terms as first names, titles + first names, group address terms, kinship terms and terms of endearment was recorded and analysed to determine the proportional use of each.

\section{Procedure}

Three coders were selected and extensively trained to familiarise them with the concepts to be analysed in order to increase their level of comfort with the training material and to give them an idea of what was expected in terms of the task requirements and attention needed for the analysis (Riffe, Lacy, and Fico 2005). Their tools of analysis were digital worksheets that consisted of an intact text and a CA table (Appendix). The coders were required to work independently so as to avoid group consensus, that is, a group sharing a certain way of understanding of certain variables which may subsequently be built into their coding and make them deviate from the coding protocol (Peter and Lauf 2002). The data analysis took four months to complete. On completion the coding was compared and it was found that the inter-reliability level among the coders was above $80 \%$ (Speech functions: 88.6 \%; Mood: 86.3 \%; Modality: $82.9 \%$; and Address terms: $89.7 \%$ ). This was deemed to be a sufficiently high level of reliability.

\section{Results}

To address the first two research questions, speech functions, mood, modality and terms of address were analysed to reveal how interpersonal relationships were constructed through English in written Vietnamese business communication. It is clear from this that there are a range of relationships between interactants reflecting status, power, affective involvement and frequency of contact.

\section{Speech functions}

These speech functions were distributed in the data as presented in Table 2.

Table 2 reveals that most texts were concerned with statements of information (approximately $65 \%$ ), for example:

(2) Mr. H/ [Company] BL just informed me that he cannot support us this shipment at SPCT due to L/C open at TT. (text 4-1-A) 
Table 2 Distribution of speech functions

\begin{tabular}{lllll}
\hline Commodity & Speech functions & & Frequency & Percentage \\
\hline goods and services & proposal & command & 167 & $25.41 \%$ \\
& & offer & 50 & $7.6 \%$ \\
information & proposition & statement & 426 & $65.4 \%$ \\
& & question & 15 & $1.7 \%$ \\
Total & & 658 & $100 \%$ \\
\hline
\end{tabular}

(3) However it is lucky that we have IVY in 3 colors available in our showroom.

(text 6-10-U)

(4) I enclosed payment proof for 1st transaction (50/\%). (text 2-19-A)

Perhaps because of the context of the data (i.e., business communication) clauses that demanded goods and services also constituted a substantial proportion of the total (25.41\%). Examples of these include:

(5) Pls check the attached file. (text 1-1-A)

(6) Please send it to me via email of hard copies. (text 5-2-D)

In contrast requests for information (questions) and the provision of goods and services (offers) accounted for only a low percentage of the speech functions. Clauses concerning offers comprised $7.6 \%$ and included examples such as:

(7) Our staff will contact you within today. (text 7-31-C)

(8) [I] will let you know in very short times. (text 1-10-H)

Questions were of the following type:

(9) Do we have this gift to our customer this year? (text 3-7-D)

(10) And when will 8 units of AIRSPACE II DISP WI LCD 6/ CASE \# 113-92024629 be available for shipment? (text 3-40-P)

\section{Mood}

The mood structures used to realise the above speech functions were distributed as shown in Table 3.

Table 3 shows the writers relied heavily on declaratives $(75.4 \%$ of texts, including full and elliptical declaratives). Imperatives were the next most frequently selected (16.2\%). The high use of these two mood structures corresponds with the high percentage of statements and commands as illustrated in Table 2. However, Table 3 shows that declaratives did not always perform the speech function of information giving. Likewise, imperatives were not only used to demand goods and services. In fact, the mood structures (as presented in Table 4) fulfilled various speech functions.

From Table 4 it can be seen that approximately $82 \%$ of the clauses demonstrated a congruency between speech functions and mood choices. This congruency suggests 
Table 3 Distribution of mood structures

\begin{tabular}{llll}
\hline Mood & & Frequency & Percentage \\
\hline Declarative & Full declarative & 438 & $63 \%$ \\
& Elliptical declarative & 88 & $12.4 \%$ \\
Interrogative & WH interrogative & 5 & $0.6 \%$ \\
& Yes-No interrogative & 20 & $2.9 \%$ \\
Imperative & & 107 & $16.2 \%$ \\
Total & & 658 & $100 \%$ \\
\hline
\end{tabular}

close relationships between the writer and recipient (Halliday and Matthiessen 2013), and that they were likely to have frequent contact and equal power relation (Eggins 2004). Further, commands inherent in the imperatives were often tempered by the politeness marker please and/or kindly:

(21) Please send it to me via email of hard copies. (text 5-2-DD)

Table 4 Congruency between speech functions and mood

\begin{tabular}{|c|c|c|c|c|c|}
\hline & & Speech functions - mood & Freq. & Perc. & Total \\
\hline \multirow[t]{8}{*}{ Congruency } & \multirow{4}{*}{$\begin{array}{l}\text { Proposals and } \\
\text { typical mood }\end{array}$} & command - imperative & \multirow[t]{2}{*}{104} & \multirow[t]{2}{*}{$15.9 \%$} & \multirow[t]{8}{*}{$82.1 \%$} \\
\hline & & (11) Please sign it and send to us. (text 7-35-C) & & & \\
\hline & & offer - interrogative & 2 & $0.2 \%$ & \\
\hline & & $\begin{array}{l}\text { (12) Do you need me to ask CDC Hanoi to } \\
\text { arrange a meeting? (text } 8-2-C \text { ) }\end{array}$ & & & \\
\hline & \multirow{4}{*}{$\begin{array}{l}\text { Propositions and } \\
\text { typical mood }\end{array}$} & statement - declarative & 426 & $64.8 \%$ & \\
\hline & & $\begin{array}{l}\text { (13) However, he can support us for future } \\
\text { shipments (text 4-1-A) }\end{array}$ & & & \\
\hline & & question - interrogative & 8 & $1.2 \%$ & \\
\hline & & $\begin{array}{l}\text { (14) Anh I oi [Hey brother I], do we have any } \\
\text { sources for this expense (text 8-61-K) }\end{array}$ & & & \\
\hline \multirow[t]{13}{*}{ Incongruency } & \multirow{10}{*}{$\begin{array}{l}\text { Proposals and } \\
\text { non-typical mood }\end{array}$} & command - modulated interrogative & 15 & $2.3 \%$ & \multirow[t]{13}{*}{$17.9 \%$} \\
\hline & & $\begin{array}{l}\text { (15) Will you confirm your mail receipt? } \\
\text { (text 9-1-A) }\end{array}$ & & & \\
\hline & & command - modulated declarative & 46 & $7.3 \%$ & \\
\hline & & $\begin{array}{l}\text { (16)...it [the report] should be submitted } \\
\text { PD Acountant asap. (text 3-3-A) }\end{array}$ & & & \\
\hline & & command - declarative & 2 & $0.2 \%$ & \\
\hline & & $\begin{array}{l}\text { (17) Please you print out the new one then } \\
\text { sign again and scan with full page same as } \\
\text { my PO and send back us. (text } 7-16-C \text { ) }\end{array}$ & & & \\
\hline & & offer - imperative & 3 & $0.5 \%$ & \\
\hline & & $\begin{array}{l}\text { (18) Have a good working week ahead. } \\
\text { (text 9-15-E) }\end{array}$ & & & \\
\hline & & offer - modulated declarative & 45 & $6.9 \%$ & \\
\hline & & $\begin{array}{l}\text { (19) We will sent draft versions to you in next } \\
\text { few days. (text 8-7-P) }\end{array}$ & & & \\
\hline & \multirow{3}{*}{$\begin{array}{l}\text { Propositions and } \\
\text { non-typical mood }\end{array}$} & statement - tag declarative & 0 & 0 & \\
\hline & & question - declarative & 7 & $0.7 \%$ & \\
\hline & & $\begin{array}{l}\text { (20) Please advise when I should send the hardcopy } \\
\text { of the letter to PACCOM (text 8-31-K) }\end{array}$ & & & \\
\hline Total & & & 658 & $100 \%$ & $100 \%$ \\
\hline
\end{tabular}


(22) Please kindly find the attached file for the list if recommended products (text 3-8-Y)

In several cases (30 \% of commands in imperatives), the close relationship between the writer and recipient expressed was enhanced by the abbreviation pls/ plz. In (23) below, this closeness was accentuated by an emoticon. In (24), the friendly relationship between the interactants was expressed by the Vietnamese kinship term anh 'older brother', while in (25), the informality was further highlighted by the salutation $H i$.

(23) Just come out today, still very hot...;) Pls see attachments. (text 6-37-U)

(24) Anh A

Older brother A

"Older brother A"

Pls submit to me your expense report for taxi cost Oct 2007 (text 1-2-Q)

(25) Hi FFFF \& GGGG: pls prepare facilities as requested. (text 5-19-EEEE)

However, the results shown in Table 4 also indicate that for approximately $18 \%$ of clauses there was an incongruent relationship between speech functions and mood choices. This incongruency was likely to be influenced by tenor dimensions such as distant relationships, power differences between the writer and recipient, or low contact and involvement (Eggins 2004). While most of these marked choices comprised proposals, that is the exchange of goods and services via commands or offers (17\%), only $0.7 \%$ of the incongruent choices were in relation to propositions (i.e., the exchange of information via statements or questions). This marked imbalance between incongruent proposals and incongruent propositions suggests that the negotiation of action received more attention, at least in terms of the wording, than the negotiation of information. Where the exchange of goods and services were concerned, it seems that the writers had a tendency to select "variation in the expression of a given meaning" (Halliday 1994: 342) as a politeness strategy in order to ask the recipient to perform an action. This was regardless of whether the action benefited the writer (i.e., requests, Lassen 2003):

(26) [Please be noted that $]$ your attendance is requested. (text 9-5-E)

(27) Could you please confirm the receipt of this email? (text 9-16-E)

Or benefited the recipient (i.e., offers, Lassen 2003):

(28) ...you are welcome [to the banquet] if you can come on that day. (text 1-8-T)

(29) ...we will [...] ship a replacement to you (text 3-4-N)

In contrast, if congruent mood structures had been selected, the above instances would have taken the following form (as illustrated in Table 5).

As can be seen in (27), by using a polarity interrogative (i.e., Yes/No interrogative), the writer provided the recipient with a choice of complying with the command or rejecting it. As Martin and Rose (2007) observe, the use of interrogatives to realise commands indicates the inequality in status between the writer and recipient. Since the 
Table 5 Illustration of congruent mood structures

\begin{tabular}{lll}
\hline Speech functions & Congruent mood & Examples \\
\hline command & imperative & (Please) attend the workshop. (text 9-5-E) \\
& & (Please) confirm the receipt of this email (text 9-16-E) \\
offer & Would you like to come to the banquet? (text 1-8-T) \\
& interrogative & Would you like us to ship a replacement to you? (text 3-4-N) \\
\hline
\end{tabular}

grammar of interrogatives corresponds with the grammar of demanding information, using this mood structure for a command positions the recipient as the one who knows the answer, "the authority in the situation" (Martin and Rose 2007: 229).

Notably, $47 \%$ of the commands in modulated interrogatives were not accompanied by question marks:

(30) Could you scan it again because I can't see the content clearly. (text 7-16-C)

(31) Can you help me to make a letter for both Can Tho and An Giang the sooner the better (text 8-29-FF)

The absence of question marks in these incongruent commands indicated the tendency to use interrogatives as declaratives (the grammar of statements), showing the writer's expectation of the recipient's compliance with the commands.

In some modulated declaratives, the commands appeared to give information:

(32) You can send us a Purchase request from now. (text 3-32-D)

(33) In the south you will visit HCM PAC and OPCs on Feb 14. (text 8-2-C)

Despite their structural form, these clauses in fact demanded goods and services. As Martin and Rose (2007: 223) point out, while negotiating information involves a verbal response, negotiating goods and services results in actions. It could be seen that the aforementioned clauses required the recipient to perform actions, such as to send a purchase request (32) or visit HCM PAC and OPCs (33). The subject choice of these clauses was you, highlighting the focus of the negotiation of action on the recipient. By borrowing the grammatical meaning of declaratives (i.e., giving information), the above clauses were, in effect, an indirect way to realise commands (i.e., demanding goods and services).

In some other modulated declaratives, the commands were framed with the modality of inclination would and with the verb of desiring like:

(34) ...we would like to ask each partner to send us a one-page briefer about their organization/activities. (text 8-51-VV)

(35) I would like to ask for your help to forward this email... (text 5-21-KKKK)

The subject typically specifies the one who is responsible for realising an offer or command (Halliday and Matthiessen 2013). However, unlike typical commands, the subjects of these command clauses, which comprised first-person reference $I$ and we, were dissociated from the actor, that is you. Nonetheless, there were elements in the 
clauses that specified the recipients as the ones responsible for the success of the proposals: each partner (34) and your help (35).

\section{Modality}

The next variable used to identify interpersonal meanings in the data was modality. The four major types of modality identified by the coders included readiness, which appeared most often, followed by probability, obligation and usuality, which was used marginally (see Table 6).

Moreover, the writers mostly employed subjective selections for modality (about $94 \%$ ), including both congruent and metaphorical realisations (see Tables 7 and 8). Objective selections, on the other hand, were rarely used (about $6 \%$ ). Moreover, the modality in the data manifested as an implicit subjective orientation with nearly $70 \%$ being finite modals. The majority of modality expressed a median-to-high degree of modal judgement, accounting for more than $80 \%$ of modality (Tables 7 and 8 ).

The modality of readiness was the largest group, comprising nearly $40 \%$ of the total instances of modality (as shown in Table 7). This high frequency of readiness modality indicated the writers' inclination to perform an action or to put forward a proposal (Eggins 2004: 172).

The implicitly subjective modal finite will was extensively employed, conveying a high degree of readiness of the proposal:

(36) The schedule will be confirmed to you soon. (text 3-25-O)

(37) Please keep us aware of any problems you have had so that prompt actions will be taken to make sure that things will go on smoothly as soon as possible. (text 9-7-E)

For metaphorical realisations of readiness, all comprised explicitly subjective clauses using the subjects $I$ or we:

(38) Im pleased to know that your company is now recruiting new staff. I would like to take this opportunity to introduce myself as a suitable candidate for position.

(text 3-5-W)

(39) We look forward to welcoming you at the club. (text 9-3-C)

As shown in Table 7, the second most frequent type of modality used in the sample was probability, making up one third of all modality samples (33.3\%). In this subgroup, roughly two thirds comprised congruent realisations, with implicitly subjective realisations may, might, will, can and could as well as implicitly objective realisations such as hopefully and certainly. The pseudo clauses with the first person $I$ and the

Table 6 Distribution of modality

\begin{tabular}{lll}
\hline Modality & Frequency & Percentage \\
\hline readiness & 184 & $39.2 \%$ \\
probability & 156 & $33.3 \%$ \\
obligation & 119 & $25.4 \%$ \\
usuality & 10 & $2.1 \%$ \\
Total & 469 & $100 \%$ \\
\hline
\end{tabular}


Table 7 Realisations of modality

\begin{tabular}{|c|c|c|c|c|c|}
\hline \multirow[t]{2}{*}{ Modality } & \multicolumn{2}{|l|}{ Congruent realisations } & \multicolumn{2}{|c|}{ Metaphorical realisations } & \multirow[t]{2}{*}{ Total } \\
\hline & Implicitly subjective & Implicitly objective & Explicitly subjective & Explicitly objective & \\
\hline \multirow[t]{5}{*}{ Readiness } & will & & I would like & & \\
\hline & can & & I want to & & \\
\hline & could & - & I am pleased to & & \\
\hline & would & & I look forward to & - & \\
\hline & & & I am happy to & & \\
\hline Percentage & $29.2 \%$ & $0 \%$ & $10 \%$ & $0 \%$ & $39.2 \%$ \\
\hline \multirow[t]{5}{*}{ Probability } & will & hopefully & I think & It is possible & \\
\hline & can & certainly & I hope & & \\
\hline & may & & I believe & & \\
\hline & might & & I know & & \\
\hline & could & & (I) trust & & \\
\hline Percentage & $22.5 \%$ & $0.8 \%$ & $9.7 \%$ & $0.2 \%$ & $33.2 \%$ \\
\hline \multirow[t]{8}{*}{ Obligation } & should & be suggested & I/We need you to & it is best & \\
\hline & could & be requested & I look forward to & it is perfect & \\
\hline & will & be obliged & We expect to & & \\
\hline & would & be urged & I hope & & \\
\hline & can & be recommended & & & \\
\hline & must & be compulsory & & & \\
\hline & have to & be in need of & & & \\
\hline & & definitely & & & \\
\hline Percentage & $15.3 \%$ & $2.2 \%$ & $6.6 \%$ & $1 \%$ & $25.1 \%$ \\
\hline \multirow[t]{2}{*}{ Usuality } & - & always, normally & - & - & \\
\hline & & in general, etc. & & & \\
\hline Percentage & $0 \%$ & $2 \%$ & $0 \%$ & $0 \%$ & $2 \%$ \\
\hline TOTAL & $67 \%$ & $5 \%$ & $27 \%$ & $1 \%$ & $100 \%$ \\
\hline
\end{tabular}

mental processes of cognition (e.g., think, believe, know, trust) were extensively used, suggesting that the writer is explicitly responsible for the evaluation of probability (Fairclough 2003). For example:

(40) I think although there is a discrepancy with our most recent SOP, the sampling is legitimate ... (text 8-5-C)

(41) I do believe we mix up some napkins in the towel wheel. (text 3-22-D)

The third group within modality was obligation, which accounted for $25.1 \%$ of the sample. Together the modalities of readiness and obligation grammatically express offers and requests (Eggins 2004; Halliday and Matthiessen 2013), and their high proportional use (readiness: $39.2 \%$ + obligation: $25.1 \%=64.3 \%$ ) reflects the texts' strong orientation to the exchange of goods and services (rather than the exchange of information).

The implicitly subjective modal should was also frequently used, conveying a median degree of obligation: 
Table 8 Values of modality

\begin{tabular}{|c|c|c|c|c|}
\hline Values of modality & High & Median & Low & Total \\
\hline \multirow[t]{6}{*}{ Readiness } & will & can & & \\
\hline & I would like & could & & \\
\hline & I want to & would & & \\
\hline & & I'm pleased to & & \\
\hline & & I look forward to & & \\
\hline & & I'm happy to & & \\
\hline Percentage & $28.1 \%$ & $11.1 \%$ & $0 \%$ & $39.2 \%$ \\
\hline \multirow[t]{11}{*}{ Obligation } & must & & can & \\
\hline & have to & should & could & \\
\hline & be requested & we expect to & will & \\
\hline & be obliged & & would & \\
\hline & be urged & & look forward to & \\
\hline & I/We need you to & & be suggested & \\
\hline & be compulsory & & I hope & \\
\hline & be in need of & & & \\
\hline & definitely & & & \\
\hline & it is best & & & \\
\hline & it is perfect & & & \\
\hline Percentage & $9.4 \%$ & $6.6 \%$ & $9.1 \%$ & $25.1 \%$ \\
\hline \multirow[t]{5}{*}{ Probability } & will & can & might & \\
\hline & I know & may & could & \\
\hline & I believe & I think & I hope & \\
\hline & I trust & & hopefully & \\
\hline & certainly & & it's possible & \\
\hline Percentage & $16.4 \%$ & $8.3 \%$ & $8.5 \%$ & $33.2 \%$ \\
\hline usuality & always, never & normally, usually, often, in general & - & \\
\hline Percentage & $0.8 \%$ & $1.2 \%$ & $0 \%$ & $2 \%$ \\
\hline TOTAL & $56 \%$ & $27 \%$ & $17 \%$ & $100 \%$ \\
\hline
\end{tabular}

(42) I know that the deadline for submitting is yesterday, but, however, it should be sent to you even late. (text 8-12-T)

(43) While negotiating with the hotel for a check out late (latest 12:30 pm), we should arrange the course finishes before 12:00 am. (text 8-15-C)

However, in some cases, the modal finite should was combined with an explicitly subjective mental clause of probability (e.g., I think) seemingly to temper the obligation. For instance:

(44) I think that we should show the very typical/classical pictures for participants as many of them may have never seen those conditions before. (text 8-11-AA)

(45) On their suggestions I think that we should get along well with their situations. (text 8-24-FF) 
$6.6 \%$ of obligation modality (Table 7) were subjectively explicit and expressed a strong degree of obligation (refer to Table 8), suggesting a frequency of contact or perhaps an unequal power relationship:

(46) As $M$ is preparing a list of things that we need you to hand-carry back to VN for Inst. so I will send it to JJ and cc you tomorrow. (text 3-15-B)

(47) One of things we need to do is making standardized reports for sites, including word and ppt template. (text 8-7-P)

The least used modality was usuality, occurring in only a few instances (2\%). All of these instances were implicitly objective. For example:

(48) Normally, it takes 01 months since application was officially submitted. (text 8-9-Q)

(49) Besides, the printed tapes are not popular and they don't usually have stock. (text 6-7-U)

\section{Terms of address}

The last variable that manifests important dimensions in the relationships between the writers and recipients is terms of address. Table 9 illustrates the distribution of terms of address in the data as coded by the observers.

First names constituted the most frequently used address terms in the current data, accounting for $34.7 \%$ of the total. Among the first names, it is worth pointing out that the vocatives of eight texts ( $2.7 \%)$ employed Vietnamese particle oi 'hey'. These vocatives were formed by first names plus oi 'hey'. This borrowing of the Vietnamese friendly vocative particle highlighted the close interpersonal relationship between the writer and the recipient. For example:

(50) Toi, I did not receive your report from Nghe An... (text 8-38-S)

$\mathrm{T}$ hey, I did not receive your report from Nghe An...

"Hey T, I did not receive your report from Nghe An..."

Other examples of first-name vocatives used with Vietnamese lexis included the use of $v a$ 'and':

Table 9 Distribution of terms of address

\begin{tabular}{lll}
\hline Terms of address & Frequency & Percentage \\
\hline first names & 105 & $34.7 \%$ \\
groups & 92 & $30.1 \%$ \\
titles + first names & 48 & $16 \%$ \\
Vietnamese kinship/respect terms & 32 & $10.1 \%$ \\
texts with no terms of address & 27 & $8.6 \%$ \\
endearment & 1 & $0.3 \%$ \\
Total & 305 & $100 \%$ \\
\hline
\end{tabular}


(51) CHUC MUNG M, T va DD

Congratulations $\mathrm{M}, \mathrm{T}$ and $\mathrm{DD}$

"Congratulations $\mathrm{M}, \mathrm{T}$ and $\mathrm{DD}$ ”

Congratulations,

A (text 8-67-A)

(52) Chao anh $M M$ va $Y$,

Hello older brother MM and Y,

"Hello older brother MM and Y,"

So when you submit the application, please let me know, so I can send the letter to PACCOM. (text 8-33-K)

The sense of familiarity was also demonstrated in other ways. For example, in the following text, the conventional salutation "Dear X", "Hello X" or "Hi X" was not used. Instead the terms $W W, U$, and $I$ were selected and also incorporated into the body of the message, conveying a sense of closeness between the writer and recipients. This informality was also exemplified by the inclusion of the written giggling Hehe.

(53) Congratulations! WW, U and I for your tireless efforts in the fighting with staircase climbing. Hehe.

$O$ (text 8-68-O)

In one email, while the message was sent to multiple recipients, one particular recipient was identified and addressed by the Vietnamese kinship term co 'auntie', showing the writer's respect to this older recipient:

(54) Dear co A and all our colleagues,

Dear auntie A and all our colleagues,

"Dear auntie A and all our colleagues,"

Please find attached file the zipped file with materials for basic nursing course.

I have tried my best, but I believe that some errors still exist somewhere.

(text 8-30-T)

This choice of Vietnamese kinship terms was found to be quite common in the data. In fact, $10.1 \%$ of the texts employed kinship terms as terms of address (Table 9), treating the recipients as family members:

(55) Dear Chi DD (text 8-17-N)

Dear older sister DD

"Dear older sister DD"

(56) Dear KK and Anh K (text 8-21-N)

Dear KK and older brother K

"Dear KK and older brother K"

Kinship terms used in salutations were not only in full forms, but also in abbreviations, showing a higher degree of informality: 
(57) Dear A. A (text 3-6-X)

Dear older brother $\mathrm{A}$

"Dear older brother A"

In one case, a Vietnamese address term other than kinship terms was employed to signify the writer's deference to the recipient's status:

(58) Dear Thay BB:

Dear teacher $\mathrm{BB}$

"Dear teacher BB:"

Thank you very much, one more time, for having given us a chance to get your

pupils to know about our school.

I hope your students will join [the school] and enjoy our programs soon.

$A A($ text 5-4-AA)

Although the recipient was addressed Thay 'teacher', the body text shows that the writer was not the recipient's student: The choice of your pupils/your students vs. our school implied that they might have worked for different schools. Nonetheless, the writer still addressed the recipient in a formal way by which a Vietnamese student addresses their class teacher. This choice of address term Thay 'teacher' demonstrated the writer's respect for the recipient's status.

Of the other address terms used, $16 \%$ comprised titles (e.g., Dr, Mr, Ms) plus first names. This phenomenon differs from Crystal's (2006) observation that titles in the Western tradition are often followed by surnames. However, this finding might be a cultural difference - something common within Vietnamese society. Below are some examples in the data:

(59) Dear Dr S [first name], (text 8-43-S)

(60) Dear Ms. D [first name], (text 7-6-E)

In one text, the term of address was personalised by possessive deictic $m y$ :

(61) My dear,

The first part is correct

It should be Sericol not Sour.

With best regards,

$D$ (text 3-22-D)

While the message started with a personalised endearment, the closing was the formal With best regards, consistent with Crystal's (2006) observation about automatically generated signatures.

\section{Discussion}

In answer to the first and second research questions, the results of the study demonstrate the vibrancy of English in Vietnamese written business communication. While it has been observed that "English seems to carry little cultural or historical baggage for 
the Vietnamese" (Mydans 1995: 16), the data illustrated a substantial number of important features that appear to mark a 'variety' of English in Vietnamese written business communication. As early as 1996, Tickoo (1996) suggested a variety of 'Vietnamese English' based on the way the Vietnamese people use the past tense. The present study, however, shows that there is more to English in Vietnamese written business communication than just past tense marking. Through an SFL analysis of the texts it appears that there are significant lexico-grammatical features of English in Vietnamese business communication that highlight the way interpersonal meanings are constructed, thus providing important data in response to the third research question.

From the data analysis, the prevalence of relationship building was clearly reflected in the texts as the writers employed several strategies to establish a close relationship with their interactants. In particular, Vietnamese kinship terms, that is addressing the recipients as family members (e.g., anh 'older brother', chi 'older sister', co 'auntie') were often used. Although English comprises a rich variety of address terms to show (non-)reciprocity of status (e.g., Mr, Mrs, Ms, Miss, Madam, Sir, Lady, my friend, sister, uncle, auntie, mate, etc., Nevala 2004), the writers in this study employed Vietnamese kinship terms in a significant number of texts, suggesting their presumably deliberate choice of signalling ingroup identity and, therefore, solidarity with the recipients. Other Vietnamese lexis, such as Chuc mung 'congratulations', va 'and', chao 'hello, and vocative particle oi 'hey', were also used from time to time, possibly in an attempt to establish positive relationships with the recipients.

In addition, the writers were observed to build relationships by allowing the recipients to question the 'truthfulness' of their propositions by the adoption of a personal, subjective discourse stance. The analysis of metaphorical modality shows that firstperson singular reference $I$ was selected frequently. The extensive use of first-person singular reference suggests that the writers presented their personal, rather than the company's, point of view. As Jensen (2009) points out, "self-mention can explicitly contribute to the development of a relationship with the readers" (p. 19), as the writers do not identify themselves with the institution. This personal stance, therefore, enables the meanings of the propositions/proposals to be expressed subjectively (Jensen 2009: 19).

This was also reflected in the frequent use of subjective modality. As presented previously, more than $90 \%$ of modality was subjective, with $67 \%$ being implicitly subjective and $27 \%$ explicitly subjective. Since subjective modality implies the writers' low level of commitment to the truth (Fairclough 2003: 166), in the current data it seemed to be used as a mechanism to allow the writers to avoid their request or commands being an imposition on the recipients. Thus, it was likely that the election of a personal, subjective stance enabled the writers to relate more effectively to the recipients than through the use of a collective, objective stance.

In addition to linguistic strategies, paralinguistic features such as emoticons, were used to enhance the interpersonal relationship between writer and recipient. 'Written' giggling was also employed, which appeared to demonstrate an attempt to boost a friendly business/workplace relationship.

Relationship building was not only reflected through the establishment of friendliness and closeness, but also through the use of politeness strategies. The data showed that 
$16 \%$ of the address terms comprised formal titles (e.g., Dr., Mr., Ms., etc.), indicating the writers' tendency to use them to achieve positive politeness effect or what BargielaChiappini and Harris (1996) term "maximisation of support" (p. 645).

\section{Conclusion}

Overall, the analysis of the findings from an interpersonal perspective has demonstrated how in this study the writers' choice and purposes impacted on the linguistic realisations of content/meaning. This seems to reiterate Eggins' (2004) observation that language is a system of values that "represents a point at which a choice has to be made" (p. 196). Thus, this study has consolidated a functional view of language, a "theory of choice" (Webster 2009: 1) to account for how interpersonal relationships were built and sustained in Vietnamese written business communication.

These findings support a view of varieties of English as involving context-motivated choices and functions, and moving away from approaches that have at their core notions of deviation from standards. As new context motivates innovation of language use (Hasan 2009: 170), the centrality of the notion of context in the study allowed for a meaningful explanation of language change, explaining why English in Vietnamese written business communication is "maintaining existing patterns and innovating new ones" (Hasan 2009: 170) that best accommodate its users in their specific contexts, both situational and cultural, assisting them to meet their socio-semantic needs linguistically. The notion of context is thus necessarily related to the notion of functionality, stressing what worked for the users in the data rather than what was right or wrong.

In addition, the findings of this study appear to confirm Mahboob and Szenes' (2010) contention that language should be considered as a meaning making resource and "not just as a marker that identifies the country/region that the user of this language belongs to" (p. 597). The English language in the data was shown to be a system of meanings and meaning potentials that users chose to (or not to) employ to conduct business while enacting relationships. Although the study unveiled systematic interpersonal features in written Vietnamese business communication, this is not to say these features apply to English communication of all Vietnamese. In fact, care has to be exercised when associating a certain semiotic system with national identities. In Mahboob and Szenes' (2010) words, "using names of countries as labels to classify language varieties is, arguably, imposing a nationalistic twist to linguistic varieties" (p. 580).

Furthermore, the findings of this study suggest a new approach to describing a variety of English. As seen throughout the study, SFL provided an effective theoretical framework and analytical tool to help describe the semiotic system that the Vietnamese users in the data employed to make interpersonal meanings. Through the employment of the descriptive apparatus of SFL, the semiotic system that was depicted emerged in its own right, without having to resort to any outside system such as comparing a variety with other varieties of Englishes (e.g., American English, British English, or Australian English). Therefore, SFL, a theory that involves a model of language made out of meanings (Matthiessen et al. 2010; Halliday and Matthiessen 2013) appears to be a suitable framework to investigate a new linguistic variety, offering an "appropriate theoretical apparatus for perceptive interpretation" of texts (Hasan 2009: 174) and a "coherent and viable account of the architecture of language as a system" (Hasan 2009: 167). 


\section{Endnote}

${ }^{1}$ Examples of the data are presented as they were found in the original texts.

\section{Appendix}

\section{Example of a data analysis worksheet}

3-3-A (text 3 - company 3 - writer A)

From: A

Sent: Friday, February 13, 2009 3:32 PM

To: E

Cc: N; O; D; M; Q

Subject: P-Dussmann Reconcil 2009-01

Dear All,

The attached file is the revised reconcil for PDL in Jan - 2009 .

Please crosscheck again.

If there was not any adjustment, it should be submitted PD Acountant asap.

Thanks and regards,

A

\section{Content analysis}

Fill in the slots with the corresponding elements in the clause. Within each category, identify the sub-categories the element belongs to.

For Speech functions, identify whether the clause is an offer (1), request (2), statement (3) or question (4).

For Mood choice, identify the mood of the clause (e.g., declarative, interrogative $\mathrm{Y} / \mathrm{N}$, interrogative Wh-, or imperative).

For Modality, identify whether the clause has any modals (e.g., probability, usuality, obligation, or readiness).

For Terms of address, identify whether the clause contains any terms of address.

\begin{tabular}{|c|c|c|c|c|c|}
\hline Clause & & $\begin{array}{l}\text { Speech } \\
\text { functions }\end{array}$ & $\begin{array}{l}\text { Mood } \\
\text { choice }\end{array}$ & Modality & $\begin{array}{l}\text { Terms of } \\
\text { address }\end{array}$ \\
\hline 1 & $\begin{array}{l}\text { Dear all, The attached file is the revised reconcil } \\
\text { for PDL in Jan - } 2009 \text {. }\end{array}$ & & & & \\
\hline 2 & Please crosscheck again. & & & & \\
\hline 3 & If there was not any adjustment, & & & & \\
\hline 4 & it should be submitted PD Acountant asap. & & & & \\
\hline
\end{tabular}

\section{Abbreviations}

CA: Content analysis; SFL: Systemic functional linguistics.

Competing interests

The authors declare that they have no competing interests.

Authors' contributions

$\mathrm{BN}$ was responsible for the collection of texts and their analysis. $\mathrm{RO}$ was responsible for supervising the project. Both authors contributed to the writing of the article. Both authors read and approved the final manuscript.

Dr. Bich H. N. Nguyen works in the School of Education at Curtin University in Western Australia. Her research interests include Systemic Functional Linguistics, Aboriginal education, and language teaching methodology.

Professor Rhonda Oliver works in the School of Education at Curtin University in Western Australia. Her research areas include language and literacy, particularly child studies of second language acquisition and indigenous education. She has published widely appearing in a number of international and national journals. 


\section{Acknowledgements}

We would like to thank the management boards of the nine companies who consented to participate in the research project. Thanks also to the anonymous writers of 303 email messages, whose English formed the backdrop of the analysis of the study.

Received: 14 April 2015 Accepted: 9 June 2015

Published online: 16 July 2015

\section{References}

Bargiela-Chiappini, Francesca, and SJ Harris. 1996. Requests and status in business correspondence. Journal of Pragmatics 26(5):635-662. 10.1016/0378-2166(96)89191-0

Bautista, MLS, \& Gonzalez, AB. 2008. Southeast Asian Englishes. In The handbook of World Englishes, ed. Braj Kachru, Yamuna Kachru and Cecil L. Nelson, 1st edn., 130-144. Carlton, Victoria: Blackwell Publishing.

Bruce, Harry J, Russel K Hirst, and Michael L Keene. 1995. A short guide to business writing. New Jersey: Prentice-Hall. Crystal, David. 2006. Language and the internet, 2nd ed. Cambridge: Cambridge University Press.

Denham, PA. 1992. English in Vietnam. World Englishes 11(1):61-69. doi:10.1111/j.1467-971X.1992.tb00047.x.

Do, $\mathrm{H}$ Thinh. 2006. The role of English in Vietnam's foreign language policy: A brief history. Paper presented at the $19^{\text {th }}$ Annual EA Education Conference. http://www.researchgate.net/publication/242696833_THE_ROLE_OF_ENGLISH_ IN_VIETNAM'S_FOREIGN_LANGUAGE_POLICY_A_BRIEF_HISTORY. Accessed 17 June, 2010.

Eggins, Suzanne. 2004. An introduction to Systemic Functional Linguistics, 2nd ed. London: Continuum.

Evans, S. 2012. Designing email tasks for the Business English classroom: Implications from a study of Hong Kong's key industries. English for Specific Purposes 31(3):202-212. http://dx.doi.org/10.1016/j.esp.2012.03.001.

Fairclough, Norman. 2003. Analysing discourse: Textual analysis for social research. New York: Routledge.

Fawcett, Robin. 2008. Invitation to Systemic Functional Linguistics through the Cardiff Grammar: An extension and simplification of Halliday's Systemic Functional Grammar, 3rd ed. London: Equinox Publishing Ltd.

Gut, U, Pillai, S, \& Don, ZM. 2013. The prosodic marking of information status in Malaysian English. World Englishes 32(2):185-197. http://dx.doi.org/10.1111/weng.12018.

Halliday, Michael AK. 1978. Language as social semiotic: The social interpretation of language and meaning. London: Edward Arnold.

Halliday, Michael AK. 1994. An introduction to functional grammar. Bodmin, Cornwall: Edward Arnold.

Halliday, Michael AK. 2009. Methods - techniques - problems. In Continuum companion to Systemic Functional Linguistics, ed. Michael Alexander Kirkwood Halliday and Jonathan Webster, 59-86. London: Continuum.

Halliday, Michael AK, and Christian Matthiessen. 2013. Halliday's introduction to functional grammar, 4th ed. London: Routledge.

Hasan, Ruqaiya. 2009. The place of context in a systemic functional model. In Continuum companion to Systemic Functional Linguistics, ed. Michael Alexander Kirkwood Halliday and Jonathan Webster, 167-189. London: Continuum.

Jensen, Astrid. 2009. Discourse strategies in professional e-mail negotiation: A case study. English for Specific Purposes 28(1):4-18. 10.1016/j.esp.2008.10.002.

Kachru, Braj, Yamuna Kachru, and Cecil L Nelson. 2006. Preface. In The handbook of World Englishes, ed. Braj Kachru, Yamuna Kachru and Cecil L. Nelson, 1st edn., xvii-xix. Carlton, Victoria: Blackwell Publishing.

Kim, C., and Sato, Y. 2013. More on Kena-passives in Singapore English. World Englishes 32(3):297-307. http://dx.doi.org/10.1111/weng.12032

Krippendorff, Klaus. 2004. Content analysis: An introduction to its methodology, 2nd ed. London: Sage

Krishnaswamy, N, and Archana Burde. 1998. The politics of Indian English: Linguistic colonialism and the expanding English empire. Delhi: Oxford University Press.

Lamb, David. 2000. English taking hold in Hanoi Vietnam snubs Russian and French. Los Angeles Times [Fort Lauderdale], April 15, p. 17A.

Lassen, Inger. 2003. Imperative readings grammatical metaphor. In Grammatical Metaphor, ed. Anne-Marie SimonVandenbergen, Miriam Taverniers, and Louise J Ravelli, 279-308. Amsterdam: John Benjamins Publishing Company.

Le, Son. 2011. Teaching English in Vietnam: Improving the provision in the private sector. (Doctoral dissertation). Victoria University, Australia. http://vuir.vu.edu.au/16055/1/Son_Le_PhD.pdf. Accessed 14 July, 2012.

Le, Trang T. 2011. Synonym substitution in English and Vietnamese. (Master dissertation). University of Da Nang Vietnam. http://tailieuso.udn.vn/bitstream/TTHL_125/3764/2/Summary.pdf. Accessed 25 September, 2012.

Mahboob, Ahmar, and Eszter Szenes. 2010. Construing meaning in World Englishes. In The Routledge handbook of World Englishes, ed. Andy Kirkpatrick, 580-598. New York, NY: Routledge.

Martin, James Robert. 2009. Discourse studies. In Continuum companion to Systemic Functional Linguistics, ed. Michael Alexander Kirkwood Halliday and Jonathan Webster, 154-165. London: Continuum.

Martin, James Robert, Christian MIM Matthiessen, and Claire Painter. 1997. Working with functional grammar. New York, NY: Arnold.

Martin, James Robert, and David Rose. 2007. Working with discourse: Meaning beyond the clause, 2nd ed. London: Continuum.

Matthiessen, Christian, Teruya, Kazuhiro, and Lam, Marvin. (2010). Key terms in Systemic Functional Linguistics. New York: Continuum.

Mydans, Seth. 1995. Vietnam speaks English with an eager accent. New York Times, April 16, p. $16 \mathrm{E}$.

Neuendorf, Kimberly A. 2002. The content analysis guidebook. Thousand Oaks: Sage.

Nevala, Minna. 2004. Accessing politeness axes: Forms of address and terms of reference in early English correspondence. J Pragmat 36: 2125-2160. doi:10.1016/.pragma.2004.02.001.

Painter, Clare. 2009. Language development. In Continuum companion to Systemic Functional Linguistics, ed. Michael Alexander Kirkwood Halliday and Jonathan Webster, 87-109. London: Continuum. 
Peter, Jochen, and Edmund Lauf. 2002. Reliability in cross-national content analysis. J Mass Commun Q 79:815-832. doi:10.1177/107769900207900404.

Poe, Roy W. 2006. The McGraw-Hill handbook of business letters, 4th ed. London: McGraw-Hill.

Riffe, Daniel, Stephen Lacy, and G Frederick Fico. 2005. Analysing media messages: Using quantitative content analysis in research, 2nd ed. Mahwah, NJ: Lawrence Erlbaum Associates, Inc

Smakman, D, \& Wagenaar, S. (2013). Discourse particles in colloquial Singapore English. World Englishes 32(3):308-324. http://doi:10.1111/weng.12033.

Tan-Chia, L, Fang, Y, \& Ang, P. 2013. Innovating the Singapore English Language curriculum through lesson study. International Journal for Lesson and Learning Studies 2(3):256-280. http://dx.doi.org/10.1108/IJLLS-03-2013-0017.

Tickoo, Asha. 1996. Learner hypothesis and past tense marking in Vietnamese English. World Englishes 15(2):183-192. doi:10.1111/j.1467-971X.1996.tb00104.x.

Tran, Tini. 1998. English may be ticket to better job in Vietnam - Education: As the prevailing political winds turn westward, it's the language of choice for those who want to move ahead in a career. Los Angeles Times, October 8, p. 8.

van Horn, Stanley Yunick. 2008. World English and global commerce. In The handbook of World Englishes, ed. Braj Kachru, Yamuna Kachru and Cecil L. Nelson, $2^{\text {nd }}$ edn., 620-642. Carlton, Victoria: Blackwell Publishing.

Watkhaolarm, P. 2005. Think in Thai, write in English: Thainess in Thai English literature. World Englishes 24(2):145-158. http://doi:10.1111/j.1467-971X.2005.00399.x

Webster, Jonathan J. 2009. An introduction to Continuum companion to Systemic Functional Linguistics. In Continuum companion to Systemic Functional Linguistics, ed. Michael Alexander Kirkwood Halliday and Jonathan Webster 1-12. London: Continuum.

Wilhelm, Kim. 1995. Vietnam VIPs sign up for English Language savvy seen as key to participating in world community. San Francisco Examiner, February 5, p. A8.

Wright, Sue. 2002. Language education and foreign relations in Vietnam. In Language policies in education: Critical issues, ed. James W Tollefson, 224-244. Mahwah, NJ: Lawrence Erlbaum.

$\mathrm{Xu}, \mathrm{Bo}$. 2012. An analysis of English business letters from the perspective of interpersonal function. English Language Teaching 5(7):75-80. doi:10.5539/elt.v5n7p75.

Submit your manuscript to a SpringerOpen ${ }^{\circ}$ journal and benefit from:

- Convenient online submission

Rigorous peer review

- Immediate publication on acceptance

- Open access: articles freely available online

- High visibility within the field

- Retaining the copyright to your article

Submit your next manuscript at $\boldsymbol{\nabla}$ springeropen.com 